\title{
GJB2 wt Allele
}

National Cancer Institute

\section{Source}

National Cancer Institute. GJB2 wt Allele. NCI Thesaurus. Code C127000.

Human GJB2 wild-type allele is located within 13q11-q12 and is approximately $6 \mathrm{~kb}$ in length. This allele, which encodes gap junction beta-2 protein, is involved in the assembly and function of gap junctions. Mutation in the gene is associated with syndromic deafness. 